\title{
Easily degradable carbon - an indicator of microbial hotspots and soil degradation**
}

\author{
Agnieszka Wolińska ${ }^{1}$, Artur Banach ${ }^{1}$ *, Anna Szafranek-Nakonieczna ${ }^{1}$, Zofia Stęniewska ${ }^{1}$, \\ and Mieczystaw Błaszczyk ${ }^{2}$ \\ ${ }^{1}$ Department of Biochemistry and Environmental Chemistry, John Paul II Catholic University of Lublin, I Konstantynów 1, \\ 20-708 Lublin, Poland \\ ${ }^{2}$ Department of Microbial Biology, Warsaw University of Life Sciences, Nowoursynowska 159, 02-776 Warsaw, Poland
}

Received June 21, 2017; accepted December 21, 2017

\begin{abstract}
The effect of arable soil was quantified against non-cultivated soil on easily degradable carbon and other selected microbiological factors, i.e. soil microbial biomass, respiration activity, and dehydrogenase activity. The intent was to ascertain whether easily degradable carbo can be useful as a sensitive indicator of both soil biological degradation and microbial hotspots indication. As a result, it was found that soil respiration activity was significantly higher $(\mathrm{p}<0.0001)$ in all controls, ranging between 30-60 vs. 11.5-23.7 $\mu \mathrm{mol} \mathrm{CO}_{2} \mathrm{~kg} \mathrm{d.m.}{ }^{-1} \mathrm{~h}^{-1}$ for the arable soils. Dehydrogenase activity was significantly lower in the arable soil (down to $35-40 \%$ of the control values, $\mathrm{p}<0.001)$ varying depending on the soil type. The microbial biomass was also significantly higher at the non-cultivated soil (512-2807 vs. 416-1429 $\mu \mathrm{g} \mathrm{g}^{-1}$ d.m., p <0.001), while easily degradable carbon ranged between $620-1209 \mathrm{mg} \mathrm{kg}^{-1}$ non-cultivated soil and $497-877 \mathrm{mg} \mathrm{kg}^{-1}$ arable soil $(\mathrm{p}<0.0001)$. It was demonstrated that agricultural practices affected soil properties by significantly reducing the levels of the studied parameters in relation to the control soils. The significant correlations of easily degradable carbon-respiration activity $\left(\rho=0.77^{*}\right)$, easily degradable carbon-dehydrogenase activity $(\rho=0.42 *)$, and easily degradable carbon-microbial biomass $\left(\rho=0.53^{*}\right)$ reveal that easily degradable carbon is a novel, suitable factor indicative of soil biological degradation. It, therefore, could be used for evaluating the degree of soil degradation and for choosing a proper management procedure.
\end{abstract}

Keywords: agriculture, carbon, degradation, microbial activity, soil

\section{INTRODUCTION}

Soils are the main pool of organic carbon on Earth, storing above $1500 \mathrm{Pg}$ of $\mathrm{C}$ in the top one metre layer. This is greater than the amount of carbon accumulated by vegetation present in the atmosphere (Zhao et al., 2014). The

*Corresponding author e-mail: abanach@kul.pl

**This work was partially financed by the National Science Centre, Poland (DEC-2013/09/D/NZ9/02482), 2014-2016. soil organic matter pool is a balance between the addition and decomposition rate of plant and animal remains. It is suggested that up to two-thirds of deposited residues are returned to the atmosphere as $\mathrm{CO}_{2}$ in a single season, whilst subsequent decomposition is significantly slower and results in the accumulation of more stable organic and less decomposed carbon forms in the soil (Li and Fang, 2002). The organic carbon cycle is a dynamic process, depending on physical and chemical conditions. Soil organic carbon (SOC) plays many functions, as it is a main determining factor of soil fertility, influencing its biological, chemical and physical properties, and protecting it against soil erosion. The SOC pool affects soil's capability to sustain plant growth as it is a source and sink of nutrients and water absorption, promotes soil aggregation and density, determines ion exchange, protects against soil reaction $(\mathrm{pH})$ due to application of agricultural chemicals, and regulates soil temperature and the vegetation period (Lal, 2004). SOC also supports the activity of bacteria, fungi, earthworms, plant roots and other soil inhabitants. Therefore, it is considered a soil degradation indicator and a factor enhancing the breakdown of soil contaminants (Šarapatka and Bednár, 2014). Organic matter consists of a wide range of $C$ compounds that vary in terms of susceptibility to biological degradation. According to a more recent classification (Breulmann et al., 2014; Strosser, 2010) based on the carbon function in soil, three groups of $\mathrm{C}$ compounds are distinguished: labile, stable and inert. Labile organic carbon is quickly reactive and susceptible to biodegradation, providing nutrients for both soil microorganisms and plants (Breulmann et al., 2014). This fraction of soil organic

(C) 2018 Institute of Agrophysics, Polish Academy of Sciences 
matter is rapidly transformed during the year. The stable carbon fraction is a reservoir of less decomposable organic matter responsible for soil cation exchange capacity (Strosser, 2010). These forms are usually bound in organicmineral aggregates (Breulmann et al. 2014). Its half-life is estimated as being even up to decades (Strosser, 2010). The most non-reactive organic matter, the inert fraction, determines the physical properties of the soil, protecting it against decomposition. It has a half-life between decades and centuries (Strosser, 2010). According to this classification, the labile carbon forms are substantially important factors supporting soil microbiological activity. As these are easily degradable, in the study they are referred to as easily degradable carbon (EDC). However, as the methods of its measurement are based on carbon oxidation using potassium permanganate (Weil et al., 2003), EDC is often called permanganate oxidisable carbon (POXC) or active C. Culman et al. (2012) indicate that POXC is a relatively new method that can quantify labile carbon both rapidly and inexpensively. Of note, studies devoted to POXC measurements and correlations with other important biological factors (i.e. respiration and enzyme activity) in soil environment are still little recognised.

Soil microbial activity is limited by EDC (Schimel and Weintraub, 2003). However, by removing this restriction (the input of labile $\mathrm{C}$ ), the activity of microorganisms significantly increases and produces microbial hotspots (Kuzyakov and Blagodatskaya, 2015). Kuzyakov (2010) defined such hotspots as small soil volumes with much faster microbiological processes than that in average soil conditions. Kuzyakov and Blagodatskaya (2015) divided hotspots into four groups, taking into account their biotic (rhizosphere, detritusphere, biopores) and abiotic (aggregate surface) origin. Three potential mechanisms for the transport of labile carbon to microorganisms have also been distinguished (Kuzyakov and Blagodatskaya, 2015):

- direct release of organics,

- advection system - transport of organics dissolved in water, and - transport by diffusion.

The key pathway in soil carbon accumulation is sequestration from plant biomass; hence, the rate of carbon accumulation and storage can be determined by the type of vegetation or amount of plant remains. These processes can also be influenced by agriculture management systems and practices. Tillage practices affect aeration in the surface level of soil profiles and thus it is expected that the rate of organic matter decomposition will be greater due to quicker carbon mineralisation via being in an aerobic state than being anaerobic. This hypothesis was confirmed by Moussa-Machraoui et al. (2010) and Moussadek et al. (2014) for Vertisols and Cambisols while there were no statistical differences between tillage and no-tillage soils (Thomas et al., 2007; Moussadek et al., 2014) for Luvisols. In these experiments, the total organic carbon pool was con- sidered, but the labile forms, as discussed above, seem to play the crucial role for microbial activity and plant cultivation. Still, studies related to EDC pools on cultivated soils versus non-cultivated and correlations with soil biological factors (especially respiration activity and dehydrogenase activity) are limited.

Thus, in the presented laboratory study, we aimed to quantify the effect of soil cultivation in comparison to noncultivated soil on a labile (bioavailable) carbon stock in seven soil types: Albic Luvisol, Brunic Arenosol, Haplic Phaezoem, Mollic Gleysol, Eutric Fluvisol, Eutric Histosol, and Rendzina Leptosol, which are characteristic for the Lublin region of SE Poland. A hypothesis was formulated that arable soils might be biologically degraded in terms of their biodiversity and microbial activity as a result of intensive agricultural practices. Bioavailable carbon analyses (or easily degradable carbon, EDC) were applied as a tool to determine how labile carbon forms affected soil microbial biomass (MB) carbon, respiration activity (RA) and dehydrogenase activity (DHA), i.e. factors reflecting microbial activity in soils. The aim was to ascertain whether EDC can be used as a sensitive indicator of the biological degradation phenomenon and a factor in the generation of microbial hotspots in the soil environment.

\section{MATERIALS AND METHODS}

The study was conducted in the south-east part of Poland, in the Lublin region $\left(51^{\circ} 13^{\prime} \mathrm{N} 22^{\circ} 54^{\prime} \mathrm{E}\right)$, a vast and important agricultural area. For the current study, 16 sites were selected (Fig. 1) based on database created by Bieganowski et al. (2013), allowing a precise return to the sampling locality (Gliński et al., 1991). Each site was described in the database of the Bank of Polish Soil Samples (BPSS) established in 1991 by the Institute of Agrophysics, the Polish Academy of Sciences in Lublin

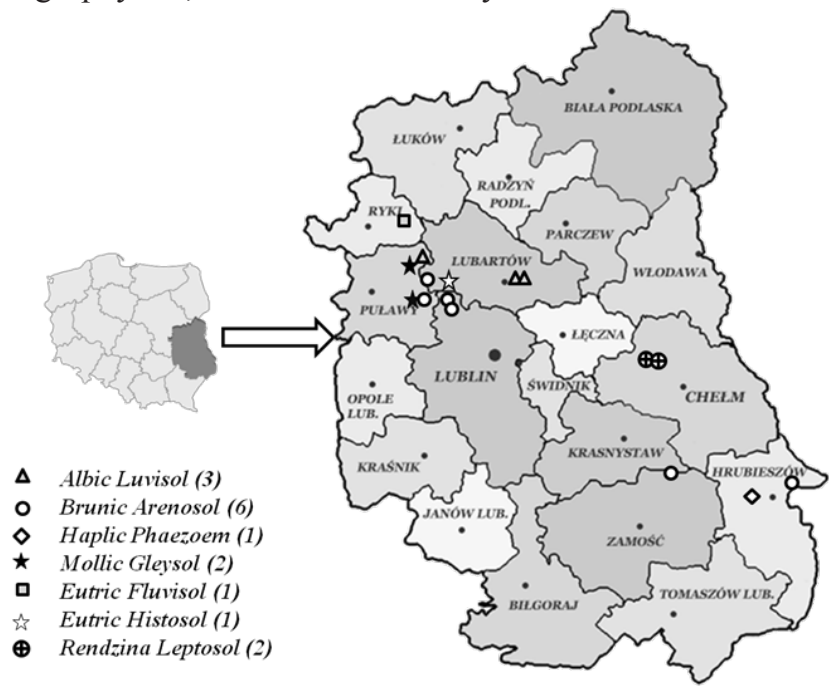

Fig. 1. Location of sampling sites in the Lublin region (SE Poland). Different symbols represent soil types and the number of sampled sites for each soil type (own image). 
(Gliński et al., 1991). At each site, both agriculturally exploited and uncultured plots were selected. The arable soils were sampled (coded A - arable) during the spring season (April 2014) from non-ploughed sites in order to avoid artefacts from ploughing perturbations (Wolińska et al., 2014). At the same time, the control samples (coded
$\mathrm{NC}$ - controls, non-cultivated soils) were taken from nonagriculturally cultivated and non-forested sites (covering at least a 1 ha area) close to the basic soils and belonging to the same soil type (i.e. fallow lands non-cultivated for years or grasslands). A description of the fields differing in the crop type and of the control site is presented in Table 1.

Table 1. Location of agricultural soils and description of the control sites used in the study

\begin{tabular}{|c|c|c|c|c|c|}
\hline Soil No. & $\begin{array}{l}\text { Type of soil } \\
\text { (FAO) }\end{array}$ & Crop type & Village & $\begin{array}{l}\text { Geographic } \\
\text { coordinates }\end{array}$ & Control sites \\
\hline 1 & & Oat & Dęba & $\begin{array}{l}22^{\circ} 10^{\prime} 17.7^{\prime \prime} \\
51^{\circ} 26^{\prime} 24.6^{\prime \prime}\end{array}$ & $\begin{array}{l}30 \text { year old meadow planted } \\
\text { with fruit trees }\end{array}$ \\
\hline 2 & $\begin{array}{l}\text { Albic Luvisol } \\
\text { (AL) }\end{array}$ & Triticale & Pryszczowa Góra & $\begin{array}{l}22^{\circ} 27^{\prime} 10.3^{\prime \prime} \\
51^{\circ} 24^{\prime} 30.8^{\prime \prime}\end{array}$ & $\begin{array}{l}20 \text { year old woodlots with } \\
\text { birches }\end{array}$ \\
\hline 3 & & Wheat & Niemce & $\begin{array}{l}22^{\circ} 36^{\prime} 51.8^{\prime \prime} \\
51^{\circ} 21^{\prime} 27.0^{\prime \prime}\end{array}$ & $\begin{array}{l}50 \text { year old meadow (mowed } \\
\text { once a year) }\end{array}$ \\
\hline 4 & & Triticale & Klementowice & $\begin{array}{l}22^{\circ} 06^{\prime} 54.2^{\prime \prime} \\
51^{\circ} 21^{\prime} 52.2^{\prime \prime}\end{array}$ & Unmoved meadow, wasteland \\
\hline 5 & & Oat & Łany & $\begin{array}{l}22^{\circ} 15^{\prime} 19.0^{\prime \prime} \\
51^{\circ} 23^{\prime} 00.9^{\prime \prime}\end{array}$ & 20 year old field-woodlots \\
\hline 6 & Brunic Arenosol & Oat & Markuszów & $\begin{array}{l}22^{\circ} 15^{\prime} 55.5^{\prime \prime} \\
51^{\circ} 23^{\prime} 10.9^{\prime \prime}\end{array}$ & 20 year old field-woodlots \\
\hline 7 & $(\mathrm{BA})$ & $\begin{array}{l}\text { Field prepared for } \\
\text { seeding }\end{array}$ & Rogalin & $\begin{array}{l}24^{\circ} 04^{\prime} 00.3^{\prime \prime} \\
50^{\circ} 51^{\prime} 15.8^{\prime \prime}\end{array}$ & $\begin{array}{l}\text { Meadow } \\
\text { (mowed once a year) }\end{array}$ \\
\hline 8 & & Triticale & Sady & $\begin{array}{l}23^{\circ} 22^{\prime} 52.4^{\prime \prime} \\
50^{\circ} 51^{\prime} 14.8^{\prime \prime}\end{array}$ & Unmoved meadow, wasteland \\
\hline 9 & & Strawberries & Chrząchówek & $\begin{array}{l}22^{\circ} 07^{\prime} 29.9^{\prime \prime} \\
51^{\circ} 25^{\prime} 50.5^{\prime \prime}\end{array}$ & Unmoved meadow, wasteland \\
\hline 10 & $\begin{array}{c}\text { Haplic } \\
\text { Phaezoem (HP) }\end{array}$ & Triticale & Hostynne & $\begin{array}{l}50^{\circ} 44^{\prime} 48.3^{\prime \prime} \\
23^{\circ} 42^{\prime} 56.6^{\prime \prime}\end{array}$ & $\begin{array}{l}\text { Meadow } \\
\text { (mowed once a year) }\end{array}$ \\
\hline 11 & Mollic Gleysol & Colza & Pożóg Nowy & $\begin{array}{l}22^{\circ} 06^{\prime} 18.8^{\prime \prime} \\
51^{\circ} 22^{\prime} 48.0^{\prime \prime}\end{array}$ & 30 year old pine woodlots \\
\hline 12 & (MG) & Wheat & Bałtów & $\begin{array}{l}22^{\circ} 01^{\prime} 25.5^{\prime \prime} \\
51^{\circ} 29^{\prime} 15.3^{\prime \prime}\end{array}$ & $\begin{array}{l}70 \text { year old meadow } \\
\text { (mowed once a year) }\end{array}$ \\
\hline 13 & $\begin{array}{l}\text { Eutric Fluvisol } \\
\qquad(\mathrm{EF})\end{array}$ & Oat & Kośmin & $\begin{array}{l}21^{\circ} 59^{\prime} 10.1^{\prime \prime} \\
51^{\circ} 333^{\prime} 47.7^{\prime \prime}\end{array}$ & $\begin{array}{l}15 \text { year old meadow } \\
\text { (mowed once a year) }\end{array}$ \\
\hline 14 & $\begin{array}{l}\text { Eutric Histosol } \\
\text { (EH) }\end{array}$ & Oat & Wólka Kątna & $\begin{array}{l}22^{\circ} 16^{\prime} 38.9^{\prime \prime} \\
51^{\circ} 25^{\prime} 27.3^{\prime \prime}\end{array}$ & $\begin{array}{l}20 \text { year old meadow } \\
\text { (mowed once a year) }\end{array}$ \\
\hline 15 & Rendzina & Celeries & Siedliszcze & $\begin{array}{l}23^{\circ} 10^{\prime} 58.3^{\prime \prime} \\
51^{\circ} 12^{\prime} 22.3^{\prime \prime}\end{array}$ & $\begin{array}{l}40 \text { year old meadow } \\
\text { (mowed once a year) }\end{array}$ \\
\hline 16 & Leptosol (RL) & Oat & Brzeziny & $\begin{array}{l}23^{\circ} 11^{\prime} 43.9^{\prime \prime} \\
51^{\circ} 12^{\prime} 10.8^{\prime \prime}\end{array}$ & $\begin{array}{l}\text { Meadow } \\
\text { (mowed once a year) }\end{array}$ \\
\hline
\end{tabular}


Soil samples were collected during 24-26 April 2014. $10 \times 10 \mathrm{~m}$ squares were chosen from the areas of the sample sites characterised by homogeneity of the vegetation cover. Generally, 16 sites represented agricultural areas and the same number of sites was taken for the controls (non-cultivated) (Fig. 1). Within each square, ca. 50 random soil samples were taken from the top layer $(0-20 \mathrm{~cm})$, using a $2.5 \mathrm{~cm}$ diameter auger. Randomised samples were drawn (due to the considerable heterogeneity of soils) in order to get the most representative soil material. In total, 3 replicates of $2 \mathrm{~kg}$ were sampled. The collected material represented 7 soil types: Brunic Arenosol (BA), Albic Luvisol (AL) (dominating soil types in Poland, representing 82\% of the country soils, thus their share in the studied material was significant -6 and 3 soil samples, respectively), Mollic Gleysol (MG), Rendzina Leptosol (RL) (2 representatives), Haplic Phaezoem (HP), Eutric Fluvisol (EF), and Eutric Histosol (EH) (all from 1 site, Table 1, Fig. 1). Under laboratory conditions, each sample was passed through a $2.0 \mathrm{~mm}$ sieve to remove large pieces of rocks and plant material was stored at $4^{\circ} \mathrm{C}$ till to the analysis.

Particle size distribution was measured using laser diffractometer (Mastersizer 2000 (Malvern, UK) with Hydro $\mathrm{G}$ dispersion units). The intensity of laser light registered on the particular detectors of the measurement system can be converted to particle size distribution according to the Mie theory, assuming the following values of the indices: refraction index 1.52 and absorption index 0.1 for the dispersed phase, and refraction index 1.33 for water as the dispersing phase. During the measurement, the pump speed was set at 1750 r.p.m., while the stirrer speed was at 700 r.p.m. (Bieganowski et al., 2013). The soils were dispersed using ultrasound at $35 \mathrm{~W}$ for 4 min without removing the organic matter (Lamorski et al., 2014). The measurements were carried out in 3 replications.

For the current study, several biochemical and chemical analyses were performed. Respiration activity (RA), expressed as $\mu \mathrm{mol}$ of the produced carbon dioxide per mass of dry soil in unit of time $\left(\mu \mathrm{mol} \mathrm{CO} \mathrm{CO}_{2} \mathrm{~kg}^{-1}\right.$ d.m. $\left.\mathrm{h}^{-1}\right)$ was determined during the soil incubation experiment (dark, tightly closed vessels, at $25^{\circ} \mathrm{C}$, for 10 days). The levels of accumulated $\mathrm{CO}_{2}$ were subsequently analysed by means of a gas chromatograph (Varian CP-3800, USA, equipped with a thermal conductivity detector $-\mathrm{TCD}\left(120^{\circ} \mathrm{C}\right)$ : Poraplot $\mathrm{Q}(25 \mathrm{~m})$ and a molecular sieve $5 \mathrm{~A}(30 \mathrm{~m})$ connected together and at $40^{\circ} \mathrm{C}$ ) at the start and the end of the incubation, always in triplicate (Szafranek-Nakonieczna and Stępniewska, 2014). Microbial biomass (MB) carbon was determined using the fumigation incubation method and calculated from the difference between $\mathrm{CO}_{2}$ evolved from fumigated (at 50\% WHC, in a vacuum desiccator, $24 \mathrm{~h}$, at $25^{\circ} \mathrm{C}$ in vapours of ethanol-free chloroform) and unfumigated soils after 10 days of incubation, and divided by conversion factor $\mathrm{Kc}=0.45$ (fraction of biomass $\mathrm{C}$ mineralised to $\mathrm{CO}_{2}$ ) (Gajda and Martyniuk, 2005). The amount of the released $\mathrm{CO}_{2}$ was measured by the $\mathrm{GC}$ method as described above. Results were expressed as $\mu \mathrm{g}$ of biomass C per gram of dry soils.

Dehydrogenase Activity (DHA) was measured spectrophotometrically ( $\lambda=485 \mathrm{~nm}$, UV-1800, Shimadzu, Japan), using tetrazolium salt: 2.3.5-TTC as a substrate (Casida et al., 1964). Easily Degradable Carbon (EDC), known also as permanganate oxidisable carbon (POXC) and synonymous with 'active carbon', was measured as follows: a $2.5 \mathrm{~g}$ soil sample was mixed with $2 \mathrm{ml}$ of $0.2 \mathrm{KMnO}_{4}$ in $1 \mathrm{M}$ $\mathrm{CaCl}_{2}$ (pH 7.2) and diluted to $20 \mathrm{ml}$, using distilled water. After 2 min of shaking (100 r.p.m.), the sample was left for $10 \mathrm{~min}$ to allow the soil to settle while being protected against light. A $0.5 \mathrm{ml}$ of a clear liquid from the upper $1 \mathrm{~cm}$ of the soil- $\mathrm{KMnO}_{4}$ suspension was then diluted 10 times, and the obtained solution was used for spectrophotometric analysis ( $\lambda=550 \mathrm{~nm}, \mathrm{UV}-1800$, Shimadzu, Japan). The calibration curve was produced using standards $0.005,0.01$ and $0.02 \mathrm{M} \mathrm{KMnO}_{4}$, in $0.1 \mathrm{M} \mathrm{CaCl}$. EDC was calculated using the following formula:

$$
\begin{gathered}
\text { Active } \mathrm{C}\left(\mathrm{mg} \mathrm{kg}^{-1}\right)=[0.02 \mathrm{~mol} / 1-(\mathrm{a}+\mathrm{b} \text { absorbance })] \\
(9000 \mathrm{mg} \mathrm{C} / \mathrm{mol})(0.021 \text { solution } / 0.0025 \mathrm{~kg} \text { soil }),
\end{gathered}
$$

where: $0.02 \mathrm{~mol} / 1$ is the initial solution concentration, a is the intercept and $\mathrm{b}$ is the slope of the standard curve, 9000 is $\mathrm{mg} \mathrm{C}(0.75 \mathrm{~mol})$ oxidised by $1 \mathrm{~mol}$ of $\mathrm{MnO}_{4}$ changing from $\mathrm{Mn}^{7+}$ to $\mathrm{Mn}^{2+}$, while 0.021 is the volume of $\mathrm{KMnO}_{4}$ solution reacted, and 0.0025 is $\mathrm{kg}$ of soil used (Weil et al., 2003; Wolińska et al., 2016).

All collected data were statistically processed by means of Statistica 9 PL (StatSoft, USA). The assumptions of parametric tests were checked with Shapiro-Wilk W statistics, and, if the assumptions were not met, $\ln (\mathrm{x}+1)$ transformation was applied. The effect of soil use and its type on the studied variables were tested using a MANOVA test, with Tukey post-hoc, followed by the analysis of regression (Pearson's $r$ or Spearman's rho depending on data normality). The significance was accepted at $p<0.05$. Data are presented as non-transformed values with either standard deviation (SD) or standard error of mean (SEM) $(n=3)$.

\section{RESULTS AND DISCUSSION}

The particle size analysis (PSD) of the studied topsoil samples revealed mainly silt loam soil type, with only the BA and EH soils being described as sandy loam types (World Reference Base for soil resources). This difference was attributed mainly to the presence of higher contents of coarser fractions, silt and sand, ranging from 17.5-63.2 and $35.1-76.6 \%$, respectively.

Our previous studies (Wolińska et al., 2014, 2016) showed that the examined soils differed in their properties depending on their type and management (Table 2). In general, the control soils had higher moisture, $\mathrm{pH}$, total carbon content, nitrite-nitrogen and ammonium concentrations, whilst nitrate-nitrogen and phosphates were higher 
Table 2. Selected soil properties (means \pm SD) depending on their type and management

\begin{tabular}{|c|c|c|c|c|c|c|c|c|c|}
\hline \multirow{3}{*}{$\begin{array}{c}\text { Type } \\
\text { AL }\end{array}$} & \multirow{2}{*}{$\frac{\text { Usage }}{\mathrm{NC}}$} & \multicolumn{2}{|c|}{ Moisture (\%) } & \multicolumn{2}{|c|}{$\mathrm{pH}$} & \multicolumn{2}{|c|}{$\mathrm{Eh}(\mathrm{mV})$} & \multicolumn{2}{|c|}{$\mathrm{TC}(\%)$} \\
\hline & & 9.97 & 0.89 & 5.85 & 0.60 bcde & 472.16 & $42.87 \mathrm{a}$ & 1.65 & $0.21 \mathrm{ab}$ \\
\hline & A & 9.13 & 0.95 & 4.89 & $0.26 \mathrm{ab}$ & 519.94 & $32.27 \mathrm{a}$ & 1.15 & $0.14 \mathrm{a}$ \\
\hline \multirow{2}{*}{$\mathrm{BA}$} & $\mathrm{NC}$ & 11.03 & 5.06 & 5.99 & 0.74 cde & 418.10 & $32.89 \mathrm{a}$ & 2.37 & $0.67 \mathrm{bcd}$ \\
\hline & A & 11.13 & 4.28 & 5.93 & 0.84 cde & 457.63 & $28.12 \mathrm{a}$ & 1.11 & $0.41 \mathrm{a}$ \\
\hline \multirow{2}{*}{ HP } & $\mathrm{NC}$ & 30.90 & 5.48 & 7.23 & $0.02 \mathrm{e}$ & 529.27 & $0.23 \mathrm{a}$ & 5.43 & $0.13 \mathrm{e}$ \\
\hline & A & 24.50 & 3.73 & 6.62 & $0.05 \mathrm{cde}$ & 561.30 & $0.36 \mathrm{a}$ & 1.64 & $0.03 \mathrm{abc}$ \\
\hline \multirow{2}{*}{ MG } & $\mathrm{NC}$ & 12.15 & 2.03 & 6.49 & $0.29 \mathrm{de}$ & 540.43 & $3.29 \mathrm{a}$ & 2.47 & $0.77 \mathrm{bcd}$ \\
\hline & A & 9.25 & 3.89 & 5.73 & 1.09 bcde & 474.40 & $205.08 \mathrm{a}$ & 1.05 & $0.15 \mathrm{a}$ \\
\hline \multirow{2}{*}{$\mathrm{EF}$} & $\mathrm{NC}$ & 8.80 & 0.25 & 5.64 & $0.03 \mathrm{abcd}$ & 545.20 & $0.40 \mathrm{a}$ & 1.23 & $0.09 \mathrm{ab}$ \\
\hline & A & 5.10 & 0.47 & 4.18 & $0.05 \mathrm{a}$ & 551.30 & $0.30 \mathrm{a}$ & 0.98 & $0.07 \mathrm{a}$ \\
\hline \multirow{2}{*}{$\mathrm{EH}$} & $\mathrm{NC}$ & 9.10 & 0.85 & 5.27 & $0.01 \mathrm{abcd}$ & 519.97 & $0.25 \mathrm{a}$ & 3.63 & $0.14 \mathrm{de}$ \\
\hline & A & 6.50 & 0.79 & 4.85 & $0.03 \mathrm{abc}$ & 523.43 & $0.23 \mathrm{a}$ & 2.69 & $0.19 \mathrm{bcd}$ \\
\hline \multirow{3}{*}{$\mathrm{RL}$} & $\mathrm{NC}$ & 15.80 & 3.72 & 6.58 & $0.90 \mathrm{de}$ & 469.98 & $26.09 \mathrm{a}$ & 3.70 & $2.32 \mathrm{cde}$ \\
\hline & A & 11.75 & 1.04 & 5.57 & $0.09 \mathrm{bcd}$ & 496.05 & $8.60 \mathrm{a}$ & 1.11 & $0.16 \mathrm{a}$ \\
\hline & & \multicolumn{2}{|c|}{$\mathrm{N}-\mathrm{NO}_{3}\left(\mathrm{mg} \mathrm{kg}^{-1}\right)$} & \multicolumn{2}{|c|}{$\mathrm{N}-\mathrm{NO}_{2}\left(\mathrm{mg} \mathrm{kg}^{-1}\right)$} & \multicolumn{2}{|c|}{$\mathrm{N}-\mathrm{NH}_{4}\left(\mathrm{mg} \mathrm{kg}^{-1}\right)$} & \multicolumn{2}{|c|}{$\mathrm{P}_{-} \mathrm{PO}_{4}\left(\mathrm{mg} \mathrm{kg}^{-1}\right)$} \\
\hline \multirow{2}{*}{$\mathrm{AL}$} & $\mathrm{NC}$ & 4.21 & $2.51 \mathrm{a}$ & 0.23 & $0.15 \mathrm{abc}$ & 0.07 & $0.02 \mathrm{ab}$ & 1.32 & $0.35 \mathrm{ab}$ \\
\hline & A & 22.83 & $22.92 \mathrm{~cd}$ & 0.08 & $0.03 \mathrm{a}$ & 0.02 & $0.00 \mathrm{a}$ & 7.91 & $8.83 \mathrm{c}$ \\
\hline \multirow{2}{*}{$\mathrm{BA}$} & $\mathrm{NC}$ & 7.69 & $3.37 \mathrm{abc}$ & 0.36 & $0.27 \mathrm{bc}$ & 0.82 & $0.86 \mathrm{bc}$ & 4.29 & $1.92 \mathrm{c}$ \\
\hline & A & 16.81 & $6.46 \mathrm{~d}$ & 0.10 & $0.03 \mathrm{a}$ & 0.18 & $0.17 \mathrm{ab}$ & 10.33 & $3.50 \mathrm{~d}$ \\
\hline \multirow{2}{*}{ HP } & $\mathrm{NC}$ & 8.23 & $0.02 \mathrm{abcd}$ & 0.44 & $0.01 \mathrm{bc}$ & 0.02 & $0.00 \mathrm{ab}$ & 1.35 & $0.02 \mathrm{abc}$ \\
\hline & A & 27.43 & $0.08 \mathrm{de}$ & 0.10 & $0.00 \mathrm{abc}$ & 0.02 & $0.00 \mathrm{ab}$ & 1.36 & $0.05 \mathrm{abc}$ \\
\hline \multirow{2}{*}{$\mathrm{MG}$} & $\mathrm{NC}$ & 8.40 & $1.82 \mathrm{abcd}$ & 0.12 & $0.02 \mathrm{ab}$ & 0.41 & $0.41 \mathrm{abc}$ & 1.39 & $0.33 \mathrm{ab}$ \\
\hline & A & 16.00 & $6.46 \mathrm{~cd}$ & 0.12 & $0.04 \mathrm{abc}$ & 2.67 & $2.48 \mathrm{~d}$ & 3.91 & $2.04 \mathrm{bc}$ \\
\hline \multirow{2}{*}{$\mathrm{EF}$} & $\mathrm{NC}$ & 2.20 & $0.05 \mathrm{a}$ & 0.13 & $0.00 \mathrm{abc}$ & 0.14 & $0.04 \mathrm{abc}$ & 1.33 & $0.01 \mathrm{abc}$ \\
\hline & A & 2.99 & $0.03 \mathrm{ab}$ & 0.11 & $0.00 \mathrm{abc}$ & 0.28 & $0.03 \mathrm{abc}$ & 2.65 & $0.09 \mathrm{abc}$ \\
\hline \multirow{2}{*}{$\mathrm{EH}$} & $\mathrm{NC}$ & 9.05 & $0.03 \mathrm{abcd}$ & 0.08 & $0.00 \mathrm{abc}$ & 0.02 & $0.00 \mathrm{ab}$ & 1.74 & $0.38 \mathrm{abc}$ \\
\hline & A & 10.22 & $0.12 \mathrm{abcd}$ & 0.09 & $0.00 \mathrm{abc}$ & 0.02 & $0.00 \mathrm{ab}$ & 3.10 & $0.10 \mathrm{abc}$ \\
\hline \multirow{2}{*}{$\mathrm{RL}$} & $\mathrm{NC}$ & 11.97 & $2.05 \mathrm{bcd}$ & 0.12 & $0.02 \mathrm{ab}$ & 0.16 & $0.13 \mathrm{ab}$ & 0.81 & $0.22 \mathrm{a}$ \\
\hline & A & 55.07 & $24.21 \mathrm{e}$ & 0.47 & $0.43 \mathrm{c}$ & 1.81 & $1.74 \mathrm{~cd}$ & 3.93 & $3.17 \mathrm{abc}$ \\
\hline
\end{tabular}

Numbers indicated by the same letter do not differ at $\mathrm{p}<0.05$ (MANOVA, comparison between soil usages and soil types). AL $-\mathrm{Albic}$ Luvisol, BA - Brunic Arenosol, HP - Haplic Phaezoem, MG - Mollic Gleysol, EF - Eutric Fluvisol, EH - Eutric Histosol, RL Rendzina Leptosol, Eh - redox potential, TC - total carbon, NC - non-cultivated soil, A - arable soil.

in the arable soils (all at least significant at $\mathrm{p}<0.05$ ). These factors could be driving forces for the changes observed in the microbial diversity and activity.

The studied soils differed substantially in microbial biomass, respiration activity and DHA in a function of the type of land use (Fig. 2). Soil RA was significantly higher $(\mathrm{p}<0.0001)$ in all the controls, ranging between 30 and
$60 \mu \mathrm{mol} \mathrm{CO} \mathrm{kg}^{-1} \mathrm{~d} . \mathrm{m} . \mathrm{h}^{-1}$, in comparison to $11.5-23.7 \mu \mathrm{mol}$ $\mathrm{CO}_{2} \mathrm{~kg}^{-1} \mathrm{~d} . \mathrm{m}$. $\mathrm{h}^{-1}$ for the A soils. We found the strongest differences for Rendzina Leptosol, Haplic Phaezoem, Eutric Fluvisol, and Brunic Arenosol (Fig. 2a) - the reduction of RA amounted to $30-40 \%$ of the control values. In general, DHA in the studied soils was significantly lower in the A sites $(p<0.001)$. However, a considerable variation in 

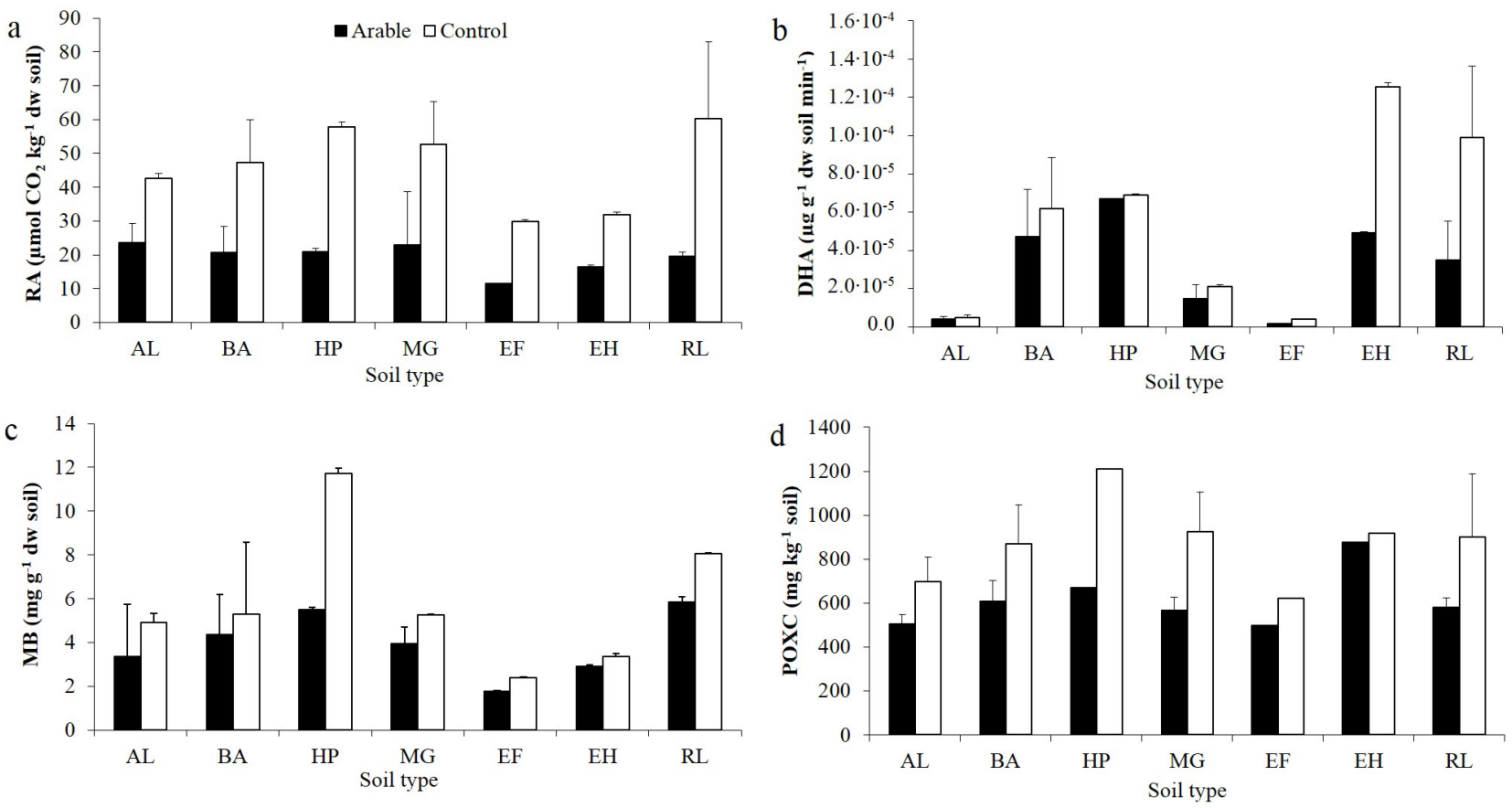

Fig. 2. Average ( \pm SEM) values of: a - respiration activity, b - dehydrogenase activity, $\mathrm{c}$ - microbial biomass, and d - easily degradable carbon for both arable and the control soils.

this parameter between the soil types was found. In Eutric Histosol and RL, the highest DHA was recorded: $1.2510^{-4}$ and $9.9210^{-5} \mu \mathrm{g} \mathrm{g}^{-1}$ d.m. soil $\mathrm{min}^{-1}$, respectively. In addition, these two sites revealed the highest reduction in DHA - down to $35-40 \%$ of the control values. BA and HP were characterised by high activity irrespective of the type of land use: 4.7-6.9 $10^{-5} \mu \mathrm{g} \mathrm{g}^{-1}$ d.m. soil $\mathrm{min}^{-1}$. Mollic Gleysol, Albic Luvisol, and Eutric Fluvisol had the lowest DHA and the lowest DHA reduction level (Fig. 2b). In general, the microbial biomass was significantly higher in the NC soils ( $p<0.001$ ); there were, however, differences depending on the soil type. The HP soil had the highest biomass of $2807.145 \mu \mathrm{g} \mathrm{g}^{-1} \mathrm{~d} . \mathrm{m}$. in the control, while most of the soils had a biomass lower by half. In the case of the other soils, the MB was in the range of 1093-1855 $\mathrm{g} \mathrm{g} \mathrm{g}^{-1} \mathrm{~d} . \mathrm{m}$. (NC soils) and 478-1429 (A soils), with the exception of EF, where it was lower than 520 (NC soils) and 420 (A) $\mu \mathrm{g} \mathrm{g}^{-1}$ d.m. (Fig. 2c).

Marschner et al. (2012) reported that hotspots are characterised by higher microbial abundance, resulting in 2-3 times greater microbial biomass in respect to bulk soil. This fact was also confirmed in our study, as we noted c.a. 2-times higher $\mathrm{MB}$ in $\mathrm{NC}$ soils than in the $\mathrm{A}$ variant. Gajda and Martyniuk (2005) observed similar MB level in agricultural soils under winter wheat as the values noted in our study. However, it should be emphasised that, usually, total MB reflects dormant microorganisms, whereas active microorganisms perform the majority of biochemical processes (Kuzyakov and Blagodatskaya, 2015). Furthermore, the active fraction is expressed by such biological para- meters as RA and DHA (Gajda and Martyniuk, 2005). We demonstrated that RA reached c.a. 3-times higher level in NC soils, analogically as DHA, with $40 \%$ higher values in $\mathrm{NC}$ rather than in A soils. In this way, we confirmed the fact that more hotspots are created in non-cultivated soils, whereas long-term and systematic soil cultivation limits hotspots development.

Easily degradable carbon, termed as biologically active and available carbon showed a similar trend as the other studied biological factors. In general, its values were significantly higher in the controls than in the agriculturally exploited soils $(p<0.0001)$. It ranged between 620 (EF) and $1209 \mathrm{mg} \mathrm{kg}^{-1}$ (HP) in the NC, and between 497 (EF) and $877 \mathrm{mg} \mathrm{kg}^{-1}(\mathrm{EH})$ in the A soils. The strongest reduction of EDC was noted in HP, MG, and RL (down to $55-65 \%$ of the control values, Fig. $2 \mathrm{~d}$ ).

Other studies have demonstrated that both organic carbon and microbial biomass are sensitive factors that quickly react to changes in management such as reduced tillage, cover cropping and land use practice (Grandy and Robertson, 2007; Wander and Bidart, 2000). This sensitivity has led to a wide adoption of these parameters in soil science as indicators of change in the soil ecosystem (GilSotres et al., 2005; Kaschuk et al., 2010).

The correlative study allowed us to verify if EDC could be used as a tool for determining the degree of soil degradation due to agricultural practices. We have found that soil microbial and biochemical activities are strongly dependent on the type of land use, which is linked with the physicochemical parameters (Wolińska et al., 2014, 2016). The 

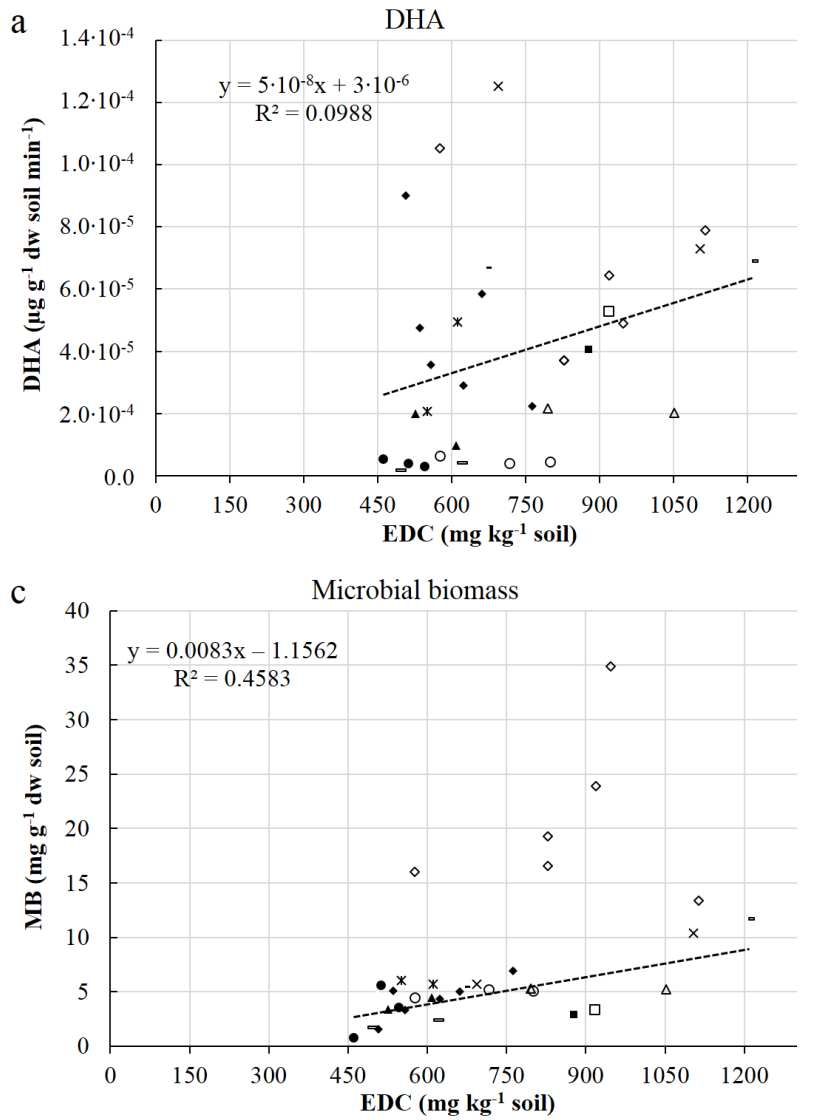

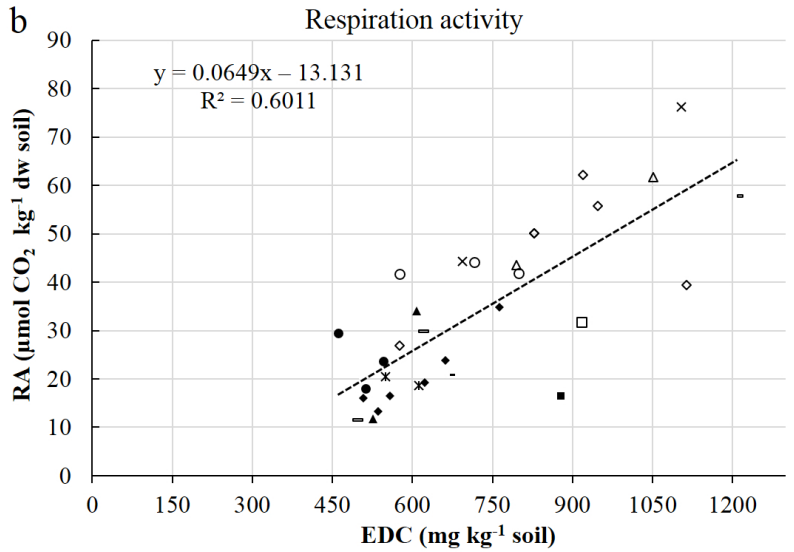

- AL-A

- BA-A

- HP-A

- MG-A

- EF-A

- EH-A

* RL-A total
- AL-NC

$\diamond$ BA-NC

- HP-NC

$\triangle \mathrm{MG}-\mathrm{NC}$

- EF-NC

$\square$ EH-NC

$\times$ RL-NC

---- Linear (total)

Fig. 3. Relationships between EDC and: a - dehydrogenase activity (DHA), b - respiration activity (RA), and c - microbial biomass (MB) for both arable and the control soils.

availability of easily degradable carbon also changed due to management practices. We revealed that this parameter was strongly reduced in all the agricultural soils (Fig. 2d). This pool of carbon is important to soil organisms and can affect their activity. It can be seen in Fig. 2 that the tested parameters were much lower in the arable soils, which confirms this statement. Also, by noting a decreasing trend in EDC content in A soils, the direct connection of EDC with hotspots creation in the non-cultivated soils was confirmed. Agricultural activities consume nutrients (including EDC), affecting their pools, which could explain their lower contents in A soils affecting soil health (Culman et al., 2012; Panettieri et al., 2015).

In order to ascertain if EDC may be a measure of soil degradation, the values of RA, DHA, and MB were plotted against the levels of EDC in the studied soils, and Spearman's rho was calculated for correlations. Very strong positive correlations were found for RA $\left(\rho=0.77^{*}\right)$ and moderate correlations for DHA $(\rho=0.42 *)$ and MB $\left(\rho=0.53^{*}\right)$. The graphical representation of the observed correlations is presented in Fig. 3. The higher values of EDC indicate stronger microbial activity in the studied soils in terms of the selected parameters. This relationship is represented by linear equations for $\mathrm{MB}$ and $\mathrm{RA}$, whilst the best equation for DHA is a power series. For the first two parameters, these equations explain 46 and $60 \%$ their variability. For DHA, it is less sound - only $19 \%$ variability in DHA may be explained by EDC.

Since both MB and EDC are based on chemical extractions of labile soil A, the agreement between these two methods is logical (Culmen et al., 2012). Weil et al. (2003) found high a positive correlation $\left(\mathrm{R}^{2}=0.72\right)$ between $\mathrm{MB}$ and EDC, whilst Culmen et al. (2012) determined the same relationship $\left(\mathrm{R}^{2}=0.44\right)$ analogically to the authors study (Fig. 3). However, studies describing the relationship between EDC and such important soil factors as RA and DHA are limited. In that context, the determination of close correlations between EDC, RA and DHA is a novel element which fills the gap of knowledge about EDC with regard to soil environment.

\section{CONCLUSIONS}

1. In the study, it was demonstrated that agricultural practices significantly affect the biological and chemical properties of soil by reducing the levels of microbial biomass, respiration activity, dehydrogenase activity and easily degradable carbon, in relation to the control soils. 
2. Consequently, the hypotheses of progressive microbiological degradation caused by soil agricultural management, and a direct connection between the level of easily degradable carbon and microbial hotspots in soils was confirmed.

3. It was demonstrated that decidedly more hotspots (taking into account easily degradable carbon input and the value of biological factors) are created in non-cultivated soils, whilst soil cultivation, except for the impact on the biological properties (decrease effect) reduces the possibility for hotspots creation.

4. Finally, by determination of Spearman rho correlation coefficient, it was revealed that easily degradable carbon can be considered a suitable factor for assessing soil biological degradation, expressed as soil respiration activity, microbial biomass and dehydrogenase activity).

5. The demonstrated sensitivity of easily degradable carbon to other biological factors and the relative ease of its measurement suggest that easily degradable carbon is a useful indicator of both the degradation phenomenon in agricultural soils and microbial hotspots indication.

\section{ACKNOWLEDGEMENTS}

The authors are grateful for Andrzej Górski participation in the field trips and help in EDC analyses, and for the assistance of Marek Pazur (from the Institute of Agrophysics Polish Academy of Sciences in Lublin, Poland) for his help in generating precise indication of places for soil sampling in strict accordance with BPSS locations.

Conflict of interest: The Authors do not declare conflict of interest.

\section{REFERENCES}

Bieganowski A., Witkowska-Walczak B., Gliński J., Sokołowska Z., Sławiński C., Brzezińska M., and Włodarczyk T., 2013. Database of Polish arable mineral soils: a review. Int. Agrophys., 27, 335-350.

Breulmann M., Masyutenko N.P., Kogut B.M., Schroll R., Dörfler U., Buscot F., and Schulz E., 2014. Short-term bioavailability of carbon in soil organic matter fractions of different particle sizes and densities in grassland ecosystems. Sci. Tot. Environ., 497-498, 29-37.

Casida L., Johnson J., and Klein D., 1964. Soil dehydrogenase activity. Soil Sci., 98: 371-376.

Culman S.W., Freeman M.A., Schipanski M.E., Beniston J., Lal R., Drinkwater L.E., Franzluebbers A.J., Glover J.D., Grandy A.S., Lee J., Six J., Maul J.E., Mirksy S.B., Spargo J.T., and Wander M.M., 2012. Permanganate oxidizable carbon reflects a processed soil fraction that is sensitive to management. Soil Sci. Soc. Am. J., 76, 494-504.

Gajda A. and Martyniuk S., 2005. Microbial biomass C and N and activity of enzymes in soil under winter wheat grown in different crop management systems. Pol. J. Environ. Stud., 14(2), 159-163.
Gil-Sotres F., Trasar-Cepeda C., Leiros M.C., and Seoane S., 2005. Different approaches to evaluating soil quality using biochemical properties. Soil Biol. Biochem., 37(5), 877-887.

Gliński J., Ostrowski J., Stępniewska Z., and Stępniewski W., 1991. Soil samples bank representing mineral soils of Poland (in Polish). Prob. Agrophys., 66, 5-57.

Grandy A.S. and Robertson G.P., 2007. Land-use intensity effects on soil organic carbon accumulation rates and mechanisms. Ecos., 10, 58-73.

Kaschuk G., Alberton O., and Hungria M., 2010. Three decades of soil microbial biomass studies in Brazilian ecosystems: Lessons learned about soil quality and indications for improving sustainability. Soil Biol. Biochem., 42, $1-13$.

Kuzyakov Y., 2010. Priming effects: Interactions between living and dead organic matter. Soil Biol. Biochem., 42, 1363-1371.

Kuzyakov Y. and Blagodatskaya E., 2015. Microbial hotspots and hot moments in soil: concept \& review. Soil Biol. Biochem., 83, 184-199.

Lal R., 2004. Soil carbon sequestration to mitigate climate change. Geoderma, 123, 1-22.

Lamorski K., Bieganowski A., Ryżak M., Sochan A., Sławiński C., and Stelmach W., 2014. Assessment of the usefulness of particle size distribution measured by laser diffraction for soil water retention modelling. J. Plant Nutr. Soil Sci., 117, 803-813.

Li X. and Feng Y., 2002. Carbon Sequestration Potentials in Agricultural Soils. Alberta Research Council: Edmonton, Alberta. http://www.aidis.org.br/ (accessed 01.06.17)

Marschner P., Marhan S., and Kandeler E., 2012. Microscale distribution and function of soil microorganisms in the interface between rhizosphere and detritusphere. Soil Biol. Biochem., 49, 174-183.

Moussa-Machraoui S., Errouissi F., Ben-Hammouda M., and Nouira S., 2010. Comparative effects of conventional and no-tillage management on some soil properties under Mediterranean semi-arid conditions in northwestern Tunisia, Soil Till. Res., 106(2), 247-253.

Moussadek R., Mrabet R., Dahan R., Zouahri A., El Mourid M., and Van Ranst E., 2014. Tillage system affects soil organic carbon storage and quality in Central Morocco. Appl. Environ. Soil Sci., ID 654796, 1-8.

Panettieri M., Berns A.E., Knicker H., Murillo J.M., and Madejón E., 2015. Evaluation of seasonal variability of soil biogeochemical properties in aggregate-size fractioned soil under different tillage's. Soil Till. Res., 151, 39-49.

Schimel J.P. and Weintraub M.N., 2003. The implications of exoenzyme activity on microbial carbon and nitrogen limitation in soil: a theoretical model. Soil Biol. Biochem., 35, 549-563.

Strosser E., 2010. Methods for determination of labile soil organic matter: An overview. J. Agrobiol., 27(2), 49-60.

Szafranek-Nakonieczna A. and Stępniewska Z., 2014. Aerobic and anaerobic respiration in profiles of Polesie Lubelskie peatlands. Int Agrophys., 28, 2, 219-229.

Šarapatka B. and Bednář M., 2014. Assessment of potential soil degradation on agricultural land in the Czech Republic. J. Environ. Qual., 16, 1-8. 
Thomas G.A., Dalal R.C., and Standley J., 2007. No-till effects on organic matter, $\mathrm{pH}$, cation exchange capacity and nutrient distribution in a Luvisol in the semi-arid subtropics. Soil Till. Res., 94(2), 295-304.

Wander M.M. and Bidart M.G., 2000. Tillage practice influences on the physical protection, bioavailability and composition of particulate organic matter. Biol. Fertil. Soils, 32, 360-367.

Weil R.R., Islam K.R., Stine M.A., Gruver J.B., and SamsonLiebig S.E., 2003. Estimating active carbon for soil quality assessment: a simplified method for laboratory and field use. Am. J. Alter. Agric., 18, 3-17.
Wolińska A., Szafranek-Nakonieczna A., Banach A., RekoszBurlaga H., Goryluk-Salmonowicz A., Blaszczyk M., Stępniewska Z., and Górski A., 2014. Biological degradation of agricultural soils from Lublin region (SE Poland). Int. J. Curr. Microbiol. App. Sci., 3(11), 558-571.

Wolińska A., Szafranek-Nakonieczna A., Zielenkiewicz U., Tomczyk-Żak K., Banach A., Blaszczyk M., and Stępniewska Z., 2016. Quantified characterization of soil biological activity under crop cultivation. J. Adv. Biol., 8(3), 1655-1665.

Zhao F., Yang G., Han X., Feng Y., and Ren G., 2014. Stratification of carbon fractions and carbon management index in deep soil affected by the grain-to-green program in China. PlosOne, 9(6), e99657, 1-10. 